\title{
The Belief in Non-Belief Ethical/Religious Exploration of Atheism
}

\author{
Dominic Umoh \\ Department of Religious and Cultural Studies \\ Akwa Ibom State University \\ Obio Akpa Campus - Akwa Ibom State, Nigeria
}

\begin{abstract}
Atheism as a philosophical stance of total non-belief in the Sacred and his reality in the world is often associated with the West. In Africa to the contrary, and here I stand to be corrected, to the best of my knowledge, I have never come across any community or single individuals that would openly deny the existence of the Supernatural. Rather, any reality that baffles and defies human intelligence is immediately attributed to the spiritual. Hence Africans are so incurably religious that the term atheism would seem to be totally meaningless. For the traditional African, to live is to believe and to believe is to live religiously in a religious universe. This paper is an attempt to underscore the falsity of the claim of atheism that a human being of whatever race and credence could exist with absolutely no commitment to anything fundamentally in terms of basic belief. It is the conviction of this paper that complete and total non-belief is impossible. Hence atheists are simply "other-believing-people" concerned perhaps with "False Absolutes". In a way, atheism is a religion; though a pseudo-religion. Our method in this paper is explorative and critically analytic.
\end{abstract}

Keywords: Atheism, Religion, Belief, Way of Life, God's Existence

\section{INTRODUCTION}

This research work fully agrees with Blanchard (2000:15) in affirming that the most fundamental questions anyone could ask are religious questions. A few of such questions are: "Who am I?", "Why am I in the world?", "Where am I heading to from here?" Most scholars agree that these questions and similar ones, dealing with a person's identity, the meaning of human life, a person's worldview and destiny are religious in nature. And scholars are equally almost unanimous that these questions lead to an even more fundamental question: "DOES GOD EXIST?"

Once plunged into such questions, we are already in the domain of religion and what it means for humanity. So the question of the existence of God (which atheists normally answer in the negative) is also the question of the existence of man who makes out the place God would occupy in his life. The most important question in religion is therefore not simply whether God exists or not, but rather whether God also exists for man; whether his existence makes any difference for man. This is whether God is present for man. Such are issues of religious belief; issues bordering on theism and its counterpart atheism. Extreme atheism professes the denial of the God-reality in human life, a reality which inspires a particular lifestyle in the believer. But this paper is poised to demonstrate the contrary, namely that complete and total non-belief in the God-reality is not human and therefore not tenable. Hence the attitude of the atheists involves misdirected beliefs which are wrongly channeled towards intra-worldly realities. The totally religion-invested day to day lifestyle of a typical African provides an excellent tool for the demolition of such atheistic claims. 


\section{RELIGION: TRUTH FOR ALL}

Religion can be classified into its subjective and objective categories. Subjectively, religion may be conceived as internal sentiment about the sacred, with belief and faith in its divinity. It is mostly in this subjective sense that the faith phenomenon is properly highlighted. The aforementioned subjective sentiment anchors on faith such that without faith nobody can really talk of any religion. It has to be mentioned here that the term "sentiment" does not in any way connote irrationality as when one is said to be sentimental or emotional; that is opaque to reason. This would amount to this popular formula attributed to the Christian author and apologist, Tertulian: Credo quia absurdum est - I believe simply because it (the religious issue in question) is absurd; that is not clear to reason (Ducat 2004: 263). Rather, sentiment in this context refers to a deep sense of assent, a commitment and submission to, a total trust in and surrender to the One that one acknowledges, loves and adores as the source of one's being; the anchor of one's existence. This Sacred, as it is called in some quarters, to use the expression of Omoregbe, is only believed to exist (1993:3). Thus the proof of God's existence is not a priority to the believer or a necessary part of the believer's preoccupation. God is not a problem to be solved by the believer, but a mystery to be lived. The Sacred is believed to exist and is accepted by faith as the believer's ALL in ALL. Faith therefore entails a fundamental option for and a perpetual dialogue with the Absolute. In this sense, religion is truth for every human.

Even objectively that is when religion is portrayed as an institution it still amounts to the community of believers, committed to the totality of practice and rites relative to the sacred as opposed to the profane (Russ1991:246). Therefore, whether considered objectively or subjectively, religion is truth, a commitment for all the living without exception. This justifies the appellation Homo Religiosus, applied to all humans in time and space.

\section{RELIGIOUS BELIEF}

Faith is the only link, the only bridge in this event of love between the human and the divine. This is because God is God and man is man; each in his own tent. God and man are not on the same footing. Therefore there is need for this connection and the only liaison between the spiritual and temporal in this regard is religious faith.

One who thinks that he can know God as we know any physical object is a dreamer. In other words, our knowledge of the deity is not scientific in the ordinary sense of the term. It is not empirical.... Here lies the source of the imaginary conflict between knowledge and faith, mathematical certainty and religious conviction, scientific proofs and religious proofs (Umoh 2012:32).

Faith is sometimes referred to as religious knowledge. It is not purely objective yet not by that very fact completely sentimental. Given that religion is like love we cannot totally rule out sentiments or emotions. In a way, there is a trustful self-surrender. As I. T. Ramsey affirms, "Belief (a major component in religion) is like love; we fall in love, we don't scheme ourselves into love" (De Pater 1988:46). Yet religion can never be reduced to complete emotionalism, often referred to as blind faith characterized by irrationality.

Faith establishes a bond of partnership between the believer and the Sacred believed to exist; the knower and the Known to a certain extent become one. The knower is always struggling to become the known. This is a stance in philosophy of religion. It is here that religious knowledge presents itself to be more engaging than mere mathematical conviction, because no sane person (even the greatest mathematician in the world) would agree to give his life in defense of his mathematical conviction, no matter his level of certitude. But many have already shed their blood for the sake of their faith in martyrdom, defending their religious stance. 
Faith... involves a stance toward some claim that is not, at least presently, demonstrable by reason. Thus, faith is a kind of attitude of trust or assent. As such, it is ordinarily understood to involve an act of will or commitment on the part of the believer. Religious faith involves a belief that makes some kind of either an implicit or explicit reference to a transcendent source (Russ 1991:246).

Through faith, the believer is in a way overpowered and made to surrender in love to the One recognized as his Author. As the saying goes, to live is to believe. Others prefer the version, "man lives by faith." Applying this to atheism, one is faced with this inevitable question: Since it is obvious that one cannot do away with belief and still remain humanly alive, what do atheists actually believe and believe in?

\section{WHAT IS ATHEISM?}

An eighteenth-century French philosopher, François-Marie Arouet, popularly known under the pen-name as Voltaire, is quoted as saying: "If any man will reason with me, let us first define our terms". Hence, to be on the safe side the meanings of some of the terms used in this paper must be looked into. Beginning with atheism, as a term, atheism just as its collateral theism is far from having a univocal meaning in all domains. In this paper however, atheism would always refer to the negation of the Christian God, the Muslim Allah or the traditional deities of African religion. "Whereas the agnostic says, "God may exist, but we shall never know," the atheist says categorically "God does not exist; there is no one there" (Chapman 1975:175). Atheism differs from agnosticism in that the agnostic simply admits not knowing enough to make an absolute truth commitment, where the atheist holds that such knowledge is impossible. Atheism is negative in the sense that it denies the possibility of the prevailing religious explanations and arguments and thus the conclusions drawn there from (Williamson 1984: 172).

For now, suffice it to say that atheism is one of man's attitudes towards God and God- related issues. By God-related issues here is meant the total and comprehensive talk about God, his nature and attributes, activities in the world and for the world, his worth and relationship for the world and humanity. This is what is meant above according to Williamson by the "prevailing religious explanations... arguments and conclusions drawn there from." All these are contained in the very meaning of the word "God" as far as believers are concerned. Atheism is the denial or the negation of these God-related issues; an affirmation of the non-existence of the divine beings and the denial of all the arguments advanced in its favour. Hence it is rightly called godlessness. In this regards Austin Cline has it right when he affirms that atheism lacks one of the basic characteristics that define religion, namely the belief in the transcendent being: "Perhaps the most common and fundamental characteristic of religion is a belief in supernatural beings - usually, but not always, including gods. Few religions lack this characteristic and most religions are founded upon it (Cline 2017) atheism.about.com/od/aboutatheism/p/AtheismReligion.htm.

The essence of god-less-ness or a-theism as the negative syllable "less" and "alpha privatum" "a" indicate is a negation. Now a negation takes its meaning only from the idea it opposes.... Atheism so conceived, is negative because it is defined by referring to theist. ... However, this negative conception consists in the denial of God's presence and existence in human life and history. Godlessness is a doctrine or attitude which consists in denying every representation of a personal God (Umoh 2012:38).

The above is atheism negatively conceived. It is the denial of theism and all that it stands for. Today, types of atheism abound depending on what the atheist turns down in the God reality. As Nietzsche (himself a tough self-proclaimed atheist) once pointed out, there are some who 
do not explicitly deny God's existence but who for one reason or another are too distracted to be bothered about God. Various people have various reasons for proclaiming themselves atheists and denying God-related issues. A typical example is well brought out in the citation here below. This extract has been chosen because of its moral relevance to the paper's topic:

A student once told me I had satisfactorily answered all his questions (about religion and perhaps its relevance to human beings). Are you going to become a Christian?" I asked. "No," he replied. Puzzled, I asked, "why not?" He admitted, "Frankly, because it would mess up the way I'm living." He realized that the real issue for him was not intellectual but moral (Little 1975:16).

Yes the point in question is that religion must oblige the believer to adopt a certain life style and abide by it. In the case above, the individual considers such too demanding and too exigent for perhaps his carefree and laissez-faire type of existence. The easiest way to disentangle oneself from god-related encumbrances is to undo, deny or at least brush aside the source of its provenance. That is to deny the very existence of the deity or at least ignore it and then one is in a way free from all deity-related encumbrances. This is the sentiment predominant in the West today. This sentiment portrays God as an intruder to one's liberty and therefore an "obstacle" to be circumvented. This involves an adoption of a laissez-aller attitude with regards to life.

Angeles (1981) has two definitions for religion. One is full supernaturalism, conceiving religion as "the belief in and worship of a divine transcendent reality that creates and controls all things without deviation from its will. While the other anchors on humanistic ideals conceiving religion as "any attempt to construct ideals and values toward which one can enthusiastically strive and with which one can regulate one's conduct (246). Basically atheism rhymes very well with the second, according to which the individual non-believer propounds his own personal ideals and theories about life, its origin, import and objectives and thereafter strives towards them to the point of converting them into his personal deities.

However, there is a positive understanding of godlessness. This category emerges as an answer to this all-important question: If the atheist does not believe in the Sacred and does not have time for it, in what does he believe and for what does he have time? These compound questions are the consequence of a particular assertion and conviction very crucial to this paper: As human beings, we are all believers in one thing or the other - the thing(s) our minds or attentions switch on to spontaneously. This means there is no absolute non-believer; someone who has nothing to hang on to as fundamental to his existence. What does the atheist believe, what does he affirm? The atheist believes in and affirms man, his world, his history, the absolute absence and non-existence of God. God's inactivity and joblessness as far as man is concerned, human existence including man's very origin, are all core issues at stake in godlessness. An important point that should never be lost sight of here is that even genuine God-believing people also believe in man, his world and his destiny, otherwise they would not be human. Yet they can never brush aside the presence and actions of God in human life, in human universe and in human history. That makes all the difference. Frans Vansina has created an entirely separate camp for people in that category, the so-called total non-believers. He labels them "OTHER-BELIEVING-PEOPLE." Members of this camp, usually designated as atheist and quickly categorized as absolute non-believers in any Absolutes, are truly speaking "believers in what they do not know" (Steeman: 47).Without knowing, they have their own absolutes and their own ideals to which they inadvertently surrender their will and endeavours. This is the origin of the pseudo religion of atheists. It is a sort of naturalism which lacks transcendence. This attitude draws from "The God is dead" philosophy propounded by F. Nietzsche. According to Nietzsche, God is dead in human heart. Or better still, man has killed 
him by eradicating Him from human life and heart. This extract from his 1882 writing paints a picture of the "infinite nothing" that reigns after God has been "killed", "buried" and therefore eliminated from human affairs:

Are we not running incessantly - backwards, sideways and forwards, in all directions? Is there still an above and a below? Are we not wandering through an infinite nothing? Is not the void yawning ahead of us? Has it not become colder? Is it not more and more night? Do the lamps not have to be lit during the day? Do we hear nothing of the noise of the gravediggers who are burying God? Do we smell nothing of the decomposition of God? The gods are decomposing! God is dead! God is dead! And we have killed him! (Chapman: 176).

From the above, one can see the origin of Nietzsche's non-belief: People living without God and behaving as if there were no God and more so, God not intervening to save his cause. This is the type of atheism emerging from God's silence in the face of blatant injustice, immorality and persecution of the innocent by the godless. Atheism signified for Nietzsche that the death of the old God in the hearts of his contemporaries in Europe would pave way for a new era and open a new horizon with a new sanitized vision for the world.

\section{ATHEISM: A PSEUDO RELIGION}

What actually is religion? What characteristics can best define religion, distinguishing it from other types of belief systems, of which atheism? Religion involves a committed and unconditional concern about divine beings and other supernatural realities. It is a belief in and commitment to these realities. From this presupposition, it has become obvious that atheism qualifies as one of the creedal systems. Its claims of absolute non-belief are therefore contradictory to its actual practice.

According to Frans Vansina, if this "committed and unconditional concern" characteristic of religion relates to a merely intra-worldly sense-giving and healing ground, as Nature, Life, Humanity or an all-round Liberation of Working People, we speak of religion in a broad sense: ecological religion, humanistic religion, Marxist religion. If however, the same concern relates to an ego-transcending totality hiding a personal divine mystery, then we use the term religion in a strict sense. Religion in a wide sense may be openly a pseudo-religion, if the ultimate and absolute meaning-giving being manifestly implies an unauthentic reduction; nation in nationalism, race in racism, matter in brute materialism, or personal enjoyment in hedonism (Vansina 1986:75).

One can now see that atheism is a misplaced value, fabricating false absolutes to replace divine transcendent realities. In this sense atheism, even the most enlightened one, is a form of idolatry. It involves misdirected beliefs which are wrongly channeled to intra-worldly affairs. When Karl Marx was attacking Christianity, his unflinching belief in economic revolution was so prominent that it turned into a religion for him. Moreover with what he considered an unholy alliance of religion with the bourgeoisies of his time, at the expense of the proletariat, he could not but consider religion as opium tranquilizing the people and rendering them insensitive to their pathetic economic plight. There is in Marxism a shift of belief from the Christian God to the god of economic and social liberation that would overturn the oppressive economic system of the proletariats.

As Marx saw it, religion caused people to think in terms of an afterlife in another world, when they should be working to change the one in which they now lived. They were driven to this, not by any inherent spiritual dimension, but by social injustice and the inhumane use of material power. What the masses failed to see was that the ruling classes were drip-feeding them with 'pie-in-the sky' religion as some kind of 
consolation in their down-trodden condition. When social and economic oppression had been removed by communism, religion... would disappear and man would live contentedly in a classless society in which the supernatural would play no part in his thinking (Blanchard: 66).

\section{ATHEISM: POSITIVE ROLE}

Paradoxically atheism has something positive to contribute even to the lives of authentic religious believers. Godlessness awakes believers to the challenges of their religious commitments. In speculative philosophy atheism is a challenge to the believer to represent his God correctly by making a clear distinction between the intention of the believer and his actual representation of God. "It compels man not to see and live God simply as an intellectual and existential Gap-filler (The Great Provider), but also an Inspirer of human and worldly commitment. Existentially, godlessness helps to portray belief also as a tension between critical questioning and a bold self-surrender. (Umoh 2012:40). Ernest Nagel notes a positive role for atheism in the formulation of a sounder world view to replace that of the rejected theism. In this case it compels believers to review their creedal system negated and rejected by atheists. From this, Nagel strongly advocates that atheism is not necessarily an irreligious concept and that the denial of theism is logically compatible with a religious outlook of life. This is because atheism is not to be identified with sheer unbelief, or with disbelief in some particular creed of religious group. Here is how he accounts for some of the positive "doctrines" that philosophical atheism seems to propagate: Firstly, they reject the notion of incorporeal but causal entities in favor of the study of identifiable and specific bodies and plural processes of nature - "a form of materialism." Secondly, "atheists generally manifest a marked empirical temper, and the methods employed in the sciences." Lastly, atheists "have generally accepted a utilitarian basis for judging moral issues this-worldly rather than otherworldly, individualistic rather than authoritarian. Accordingly, atheistic moral reflection is vigorous call to intelligent activity for the sake of realizing human potentialities and for eliminating whatever stands in the way. ${ }^{1}$ In a way some thinkers are of the opinion that atheists may be both sincerely religious in the broad sense of the word and highly ethical (Robinson 1964).

\section{ATHEISM: THE AFRICAN PERSPECTIVE}

Here, my mind goes right back to an uproar during one of my Master's Degree defenses in Europe in 1988. The panel of judges burst out jeering at me because I appeared too illogical to be sensible by affirming that "Atheism is a non issue for Africans." Actually, by that I meant the type of self-acclaimed atheists that were prevalent in Europe at the time. During the time in question, many apparently illustrious scholars were making a lot of noise in the media declaring their total non-belief in God and in the God-affairs and canvassing for associates. They even had an Association of Non-Believers, sometimes called the Liberals, with registered members and political slant. In my own case, after my remark and consequential outburst of laughter, it took a chunk of philosophical arguments on my part to restore a bit of calm necessary to re-establish dialogue with them trying to convince them that in traditional Africa, morality meant to live religiously in a religious universe and therefore that it would be difficult to find professed non-believers on the African continent. The issue at stake is very simple: In Africa, religion infiltrates into all nooks of the people's lives and activities to the point that it may become practically impossible to separate religion from life or to envisage any dimension

${ }^{1}$ Nagel E. (1961)“Philosophical concepts of Atheism,” in Basic Beliefs: The Religious Philosophies of Mankind, ed. J. E. Fairchild (New York: New America, Library) preface, p.1. 
of the African life that is religion-free. Therefore in the nutshell, in Africa everybody appears to be a believer in one thing or the other. Here an expert in African traditional religion agrees: Religion is a universal part of human life. It must, therefore, have a great and important value otherwise by now most people in the world would have abandoned it completely. In the case of African Religion ... (it) goes all the way back into African history. It is as if African peoples do not know how to live without religion (Mbiti 1075:195).

There is one peculiarity about African culture: It is entirely religion-oriented, too religionfriendly, too religion-infiltrated and too religion-infested. Because of this, there is hardly any sector of African culture that is completely devoid of religious entanglements. In fact, religion infiltrates into all nooks and crannies of the African life: Its socials, politics, agriculture, commerce, recreations, marital affairs, family, child birth and child rearing. To substantiate a bit, let us look at the names of the weekdays and market days in some tribes, say Ibibios or Annangs of Nigeria. They are all couched after gods, goddesses or deities of the land. Personal names of individuals are also drawn from such weekday or market day names. In most African communities, kinship relations are co-extensive with religion, for one's religion is always the religion of their forefathers. That is why African traditional religion does not preach canvassing for converts, for one is born into the religion of his ancestors. Hence without exception everybody in each community is bound to the same belief system: about life, death and the afterlife, ancestors, deities, spirits and spirit possession, religious specialists and divination, sacrifice, sins and expiatory offering, cause of sickness and curing process, barrenness, fertility, child birth and child rearing, ecology and agriculture etc.

African indigenous religion has its own peculiarities, the greatest of which is that it is inseparably mixed up with the socio-cultural life of the people. Unlike Christianity or Islam, it has no founder and no date of origin. In illo tempore - "Once upon a time" is its stance. Due to the absence of the art of writing before the arrival of the Europeans in the $19^{\text {th }}$ century, this religion has no written scriptures; it has no Bible or Koran. As the African culture itself, it is handed down by means of oral tradition from one generation to another. Religion is ingrained and engraved on the community life of the people. Hence African religion is inseparable from the day to day living of individuals, such that there seems to be no atheists in the sense of a total non-believer. The Africans are said to be incurably religious. As J. Mbiti insists

Chapters of African religions are written everywhere in the life of the community, and in the traditional society there are no irreligious people. To be human is to belong to the whole community, and to do so involves participating in the beliefs, ceremonies, rituals and festivals of that community. A person cannot detach himself from the religion of his forefathers, for to do so will be detaching from his roots, his foundation, his context of security, his kinships and the entire group of those who make him aware of his own existence. To be without one of these corporate elements of life is to be out of the whole picture. Therefore to be without religion amounts to a selfexcommunication from the entire life of society, and African peoples do not know how to exist without religion (Mbiti, 1980:40).

Religion cuts across the entire spectrum of African life. Hence wherever the African is, there is his religion: He carries it to the farm - sowing and harvesting new crops. The new yam festival is just one of such episodes. Among the Annangs of South-eastern Nigeria religious features abound in the ikon, ifang, awire, ndok agricultural festivals. In fact their very essence is to bestow abundant blessings of God, of other deities and ancestors on their farmlands and farm products and the community at large. Even community festivals as title-taking, initiations are religiously couched. In many African languages there is no word for religion as such, for 
religion is co-extensive with community. There may be shrines or groves where sacrifices can be offered, but there are neither churches nor cathedrals in traditional African societies; religion is in the community enshrined in the lives of community members. The spiritual world of the African people is very densely populated with spiritual beings and the living dead (ancestors). This spiritual universe is a unit with the physical. These two intermingle and dovetail into each other, such that it is not easy to draw a dividing line.

\section{THE AFRICAN WORLDVIEW}

The world for an African person is a single entity. The heaven hangs so low that it embraces the earth. There is no sharp demarcation between entities and denominations. Rather there is a mutual blending among the various types of being, parts of the universe and their respective departments. There is also what J. Mbiti calls 'Compenetration' depicting the various layers of hierarchical structures of the same entity and the co-extensive nature of being from the outermost to the innermost level. The onion normally provides the best illustration of what Mbiti means here.

Because traditional religions permeate all the departments of life, there is no formal distinction between the sacred and the secular, between the religious and nonreligious, between the spiritual and the material areas of life. Wherever the African is, there is his religion: he carries it to the fields where he is sowing seeds or harvesting a new crop; he takes it with him to the beer party or to attend a funeral ceremony; and if he is educated, he takes religion with him to the examination room at school or in the university; if he is a politician he takes it to the house of parliament (Mbiti: 40).

The implications of all these for our topic are enormous. Primarily, man finds himself caught up entirely in a religious web from which it is practically impossible to disentangle himself. And in such a scenario, how can anybody be considered a total non-believer?

\section{CONCLUSION}

The research paper has just rounded up its itinerary exploring philosophical non-belief and its impact on the religious and moral behaviour of people. It was exploring the belief harboured in non-belief. From its expedition it has come face to face with certain facts resulting from the atheistic presuppositions. Prominent among these is the impossibility of complete and total incredulity as propounded by radical atheism. Hence the position of this paper is that a total non-belief is absolutely not possible. It does not augur well with the very nature of man who is said to live by faith. Philosophical atheists are those who, perhaps inadvertently, profess their allegiance and adherence to intra-worldly absolutes idealized by them as substitutes to the God of theism or any supernatural reality for that matter. Such a belief pattern inevitably leads to Christian idolatry. It has also been discovered that atheism and its consequential moral/religious attitudes, are mostly prevalent in the West. The reason for this is simple: it is the result of secularism which found its solidarity in the scientific revolution of the $17^{\text {th }}$ century. From here this research dares affirm that when, or rather if the economic situation in Nigeria improves, there would be a dramatic cut in the excessive belief that is in vogue right now. Prosperity gospel preachers would lose a chunk of their members.

In the same vein our research discovered that Africans are too religious and sometimes sheepishly so. This is to nobody's credit. In their economic desperateness some seem "to give their hearts" to just any proposed article of faith. In matter of faith, many Africans drink unfiltered and such attitudes lead to the blossoming of superstition. Hence our conclusion is that in Africa there appears to be no atheists. But are Africans by this very fact more advantageous in moral/religious terms than the West? Very ironically No! The incredulity of the West wears the same ethical/religious mask as the extreme credulity of many African 
believers. Not believing at all leads to the same religious and moral consequences as believing too much or believing just anything and even the rationally untenable. In philosophy of religion one would say that credulity mars authentic religious belief as incredulity. Therefore there is a necessity to strike the balance.

\section{References}

Angeles P. (1981) Dictionary of Philosophy (New York: Barnes and Nobles)

Blanchard J. (2000) Does God Believe in Atheism? (England: Evangelical Press)

Chapman C. (1975) Christianity on Trial (Wheaton, Illinois: Tyndale House)

Cline A. (2017) "Is Atheism a Religion?" atheism.about.com/od/aboutatheism/p/AtheismReligion.htm

De Pater W. (1988) Analogy, Disclosure and Narrative Theology (Leuven: Acco)

Ducat P. \& Montenot J. (Ed.) (2004) Philosophie, Le Manuel (Paris: Ellipses Édition Marketing S. A.)

Little, P. (1975) Know Why You Believe (Wheaton: Victor Books)

Mbiti J (1980) African Religions and Philosophy (London: Heinemann)

Mbiti J. (1975) An Introduction to African Religion (London: Heinemann)

Nagel E. (1961) “Philosophical concepts of Atheism,” in Basic Beliefs: The Religious Philosophies of Mankind, ed. J. E. Fairchild (New York: New America, Library)

Omoregbe, J. (1993) A Philosophical Look at Religion (Lagos: Joja Educational Publishers)

Robinson R. (1964) An atheist's Values (Oxford: Clarendon Press).

Russ, J. (1991) Dictionnaire de philosophie (Paris: Bordas)

Steeman, T. "Psychological and Sociological Aspects of Modern Atheism" in Concilium, vol. 23, 47.

Umoh D. (2008) "Philosophical Truth versus Religious Faith - A Philsophical Critique" WAJOS West African Journal of Philosophical Studies. Vol. 2. No.3: 125-139.

Umoh D. (2012) A Philosopher looks at Religion (Port Harcourt: University of Port Harcourt Press)

Vansina F. (1986) Ancient Symbols and Modern Myths (Leuven: Acco)

Williamson, W. (1984) Decisions in Philosophy of Religion (New York: Prometheus Books) 